\title{
KEWENANGAN WALI DALAM MENENTUKAN PERNIKAHAN JANDA YANG BELUM DEWASA MENURUT IMAM AI - SYAFI'I
}

\author{
Rahmat Aripin \\ Pembina Ponpes Tahfidz al-Ikhlas Riau \\ rahmataripinaripin@gmail.com
}

\begin{abstract}
A woman who has never been married. The mariage must be approved by her legal guardian, namely her father or grandfather. A woman who wants to get married must have a legal guardian. The guardian in the school of Imam Al-Shafi"i is one of the requirements that must be fulfilled. A father may arrange a marriage for a virgin woman with a man who is at the same level without her permission whether she is still immature or mature by having a comparable dowry. In other words, she may be forced by her legal guardian, father or grandfather, to get married without her permission. However, for a widow who is immature, Imam Al-Shafi'i stated that her father should not force her to get married before she is mature. Imam Al-Shafi"i prohibits the guardian in this case is a father to arrange a marriage for an immature widow because Imam AlShafi"i adheres to the virginity. A mature woman may be forced while an immature widow may not be forced because the widow is considered to be no longer a virgin.
\end{abstract}

Keywords: marriage guardian, widow, adult age.

\section{Pendahuluan}

Wali dalam nikah merupakan

hal yang sangat penting dan menentukan, bahkan menurut Imam al-Syafi"i tidak syah nikah tanpa adanya seorang wali bagi pihak perempuan. Sedangkan bagi pihak laki-laki tidak diperlukan wali nikah untuk syahnya nikah. (Azmi, 2015, p. 110) Imam al-Syafi"i berpendapat bahwa perempuan yang masih kecil dan belum baligh, ayah atau kakeknya berhak untuk menikahkannya tanpa harus meminta izin kepadanya terlebih dahulu, karena ia belum banyak memahami ber bagai hal tentang pernikahan, (alSyafi'i, th, p. 69) tetapi untuk janda yang belum dewasa, Imam al-Syafi"i berpendapat bahwa wali tidak boleh memaksa untuk menikahkannya, meskipun janda tersebut belum dewasa. Pertanyaan yang muncul adalah apa yang melatar belakangi Imam al-Syafi"i sehingga tidak boleh memaksa janda yang belum dewasa ini. Hal inilah yang harus diteliti kondisi sosial, politik dan rasio historis yang mengitari kehidupan Imam al-Syafi"i.

\section{Metode Penelitian}

Penelitian ini merupakan penelitian kepustakaan ( library research), dengan menggunakan metode content analisys ( analisis isi ). Metode analisis ini merujuk kepada analisis yang integrative yang secara konseptual berguna untuk menemukan, mengidentifikasi, dan menganalisis buku-buku figh Imam al-Syafi"i. Jenis penelitian ini adalah penelitian hukum yang bersifat normatif Sumber datanya berasal dari data primer yaitu kitab al-Umm, data sekundernya yaitu buku-buku 
figh yang berhubungan dengan penelitian.

\section{Pembahasan}

\section{Wali dalam Pernikahan}

Perwalian dalam istilah figh islam disebut dengan al-walayah (al-Wilayah ), seperti kata aldalalah yang juga bisa disebut dengan al-Dilalah. Secara etimologi dia memiliki beberapa arti. Diantaranya adalah cinta ( almahabbah ) dan pertolongan ( alnashrah ). (Suma, 2004, p. 203) ( الولي ), yakni orang yang mempunyai kekuasaan . Hakikat dari alWalayah ( Al-Wilayah) adalah " tawally al-amr " "( mengurus / menguasai sesuatu) (Suma, 2004, p. 203) Dalam perkawinan wali itu adalah seseorang yang bertindak atas nama mempelai perempuan dalam suatu akad nikah. Akad nikah dilakukan oleh dua belah pihak, yaitu pihak laki-laki yang dilakukan oleh mempelai laki-laki itu sendiri dan pihak perempuan yang dilakukan oleh walinya. (Syarifuddin, 2012, p. 91) Orang yang berhak menempati kedudukan wali itu ada tiga kelompok:

a. Wali al-Nasab, yaitu wali yang berhubungan tali kekeluargaan dengan perempuan yang akan kawin. Wali al-Nasab apabila diurutkan secara lebih rinci adalah sebagai berikut :

1. Ayah kandung

2. Kakek ( dari garis ayah ) dan seterusnya ke atas dalam garis laki-laki.

3. Saudara laki-laki sekandung.

4. Saudara laki-laki seayah.

5. Anak laki-laki saudara laki- laki sekandung.

6. Anak laki-laki saudara laki- laki seayah

7. Anak laki-laki dari anak laki- laki saudara laki-laki sekandung.

8. Anak laki-laki dari anak lakilaki saudara laki-laki seayah.

9. Saudara laki-laki ayah, sekandung ( paman )

10.Saudara laki-laki ayah seayah ( paman seayah )

11.Anak laki-laki paman sekandung.

12.Anak laki-laki paman seayah.

13.Saudara laki-laki kakek sekandung.

14.Anak laki-laki saudara laki- laki kakek sekandung.

15.Anak laki-laki saudara laki- laki kakek seayah. (Rofiq, 1977, p. 67)

b. Wali al-Mu"tiq, yaitu orang yang menjadi wali terhadap perempuan bekas hamba sahaya yang dimerdekakannya

c. Wali al-Hakim, yaitu orang yang menjadi wali dalam kedudukannya sebagai hakim atau penguasa. (Syarifuddin, 2012, p. 75)

\section{Biografi Imam al-Syafi'i}

Nama lengkap Imam al-Syafi"i adalah Muhammad Ibn Idris alAbbas Ibn Utsman Ibn al-Syafi"i lbn al-Sa"id Ibn „Ubaid Ibn „Abd Yazid Ibn Hasyim Ibn „Abd al-Muthallib Ibn „Abd Manaf. Nama al-Syafi"i diambil dari nama kakeknya, al- Syafi"i dan Qussay bin Kilab merupakan kakek nabi Muhammad SAW Pada Abdul al-Manaf nasab al- Syafi"i bertemu dengan Rasulullah SAW. Imam alSyafi"i dilahirkan di Gaza ( Palestina ) tahun $150 \mathrm{H}$ pada akhir bulan Rajab. (Pamungkas dan Surahman, 2015: 28, p. 27)

Menurut riwayat menerangkan, ketika itu keluarga Imam al-Syafi"i telah mengadakan perhitungan bahwa hari wafatnya Imam Abu 
Rahmat Aripin : Kewenangan Wali Dalam Menentukan Pernikahan Janda Yang Belum Dewasa Menurut Imam Al - Syafi'l

DOI:10.24014/af.v18.i1.7062

Hanifah bertepatan dengan hari kelahiran Imam al-Syafi"i. Berdasarkan riwayat ini. Sebagian Ahli Tarikh mencatat, hari lahir Imam alSyafi"i bertepatan dengan hari wafatnya Imam Hanafi.Bahkan menurut riwayat lain, pada bulan dan tahun itu juga Imam Ibnu Juraij al- Maliki meninggal, seorang alim ulama besar di Kota Mekkah yang terkenal sebagai Imam Ahli Hijaz. Dengan adanya dua peristiwa wafatnya dua Imam besar, maka para ahli meramalkan bahwa pribadi Imam al-Syafi"i akan menggantikan kedudukan kedua Imam besar tadi, khususnya keahlian dalam urusan pengetahuan.(Chalil, 2016, pp. 165166)

Ayahnya adalah Muhammad bin Idris bin Abbas bin Utsman bin al- Syafi"i bin Sa"ib bin Ubaid bin Abdun Yazid bin Hasyim bin alMutthalib bin Abdul al-Manaf bin Qushai bin Kilab bin Murrah. Ibunya Adalah Fatimah binti Abdullah bin Hasan bin Husain bin Ali bin Abi Thalib.(al-Syafi'i, th, p. 3)

Semasa mudanya Imam alSyafi"i hidup dalam kemiskinan, sehingga beliau terpaksa me ngumpulkan batu- batu yang baik, belulang, pelepah tamar dan tulang unta untuk ditulis diatasnya. Kadangkala beliau pergi ketempat orang banyak untuk meminta kertas untuk menulis pelajarannya.(alSyafi'i, th, p. 3)

Penampilan secara fisik Imam al- Syafi"i hanya bertubuh sedang bahkan cenderung kurus. Walaupun penampilannya sederhana namun selalu rapi dan bersih. Kelebihannya justru pada suaranya yang sangat merdu,terutama ketika melantunkan ayat-ayat suci al-Quran. Bahkan orang-orang yang mendengarkan bacaannya banyak yang menjadi takjub serta beruraian air mata. Kefasihannya serta keindahan suaranya tidak ada yang dapat menandinginya, khususnya pada masanya tersebut. (Pamungkas dan Surahman I. d., 2015: 63)

Al-Syafi"i kecil selalu mengikuti kegiatan mengajar sang guru, hingga akhirnya beliau mampu menghafal al- Qur"an pada usia tujuh tahun. Tekad belajarnya yang sangat tinggi dapat mengalahkan kefakiran yang dialaminya sedari muda. Imam al- Syafi"i muda telah mulai mengikuti berbagai majelis serta halaqah. Tak kenal lelah tak kenal menyerah. Niat bulat ingin menuntut ilmu hingga akhir hayat membuat Imam al-Syafi"i dengan bantuan ahli Hadist bernama Sufyan bin Uyainah berhasil menghafalkan al-Muwattha" Imam Malik pada usia yang baru memasuki sepuluh tahun. (Pamungkas dan Surahman, 2015: 28) Imam al-Syafi"i mendapatkan ilmunya dari banyak guru yang tersebar diseluruh negeri Islam dan para Fuqaha" yang tersebar di negeri itu. Adapun bebarapa guru Imam al-Syafi"i di antaranya adalah:

1. Muslim bin Khalid Al-Zanji, Mufti Makkah tahun $180 \mathrm{H}$ yang bertepatan dengan tahun $796 \mathrm{M}$, ia adalah maula ( budak ) Bani Makhzum.

2. Sufyan bin Uyainah al Hilali yang berada di Makkah, ia adalah salah seorang yang terkenal ke tsiqah- annya ( jujur dan adil )

3. Ibrahim bin Yahya, salah seorang ulama madinah.

4. Malik bin Anas. Al-Syafi"i pernah membaca kitab al- Muwaththa" 
kepada Imam Malik setelah ia menghafalnya di luar kepala, kemudian ia menetap di Madinah sampai Imam Malik wafat tahun $179 \mathrm{H}$, bertepatan dengan tahun $795 \mathrm{M}$.

5. Waki" bin Jarrah bin Malih alKufi

6. Hammad bin Usamah al Hasyimi al-kufi

7. Abdul Wahhab Majid al Bashri (al-Syafi'i, th, pp. 3-4)

Adapun kitab-kitab karangan beliau yang hingga sekarang masih tercatat, adalah sebagai berikut:

1. Kitab al-Risalah. Kitab ini khusus berisi ilmu ushul. Menurut riwayat, beliau mengarang kitab ini ketika masih remaja. Penyebab beliau mengarang kitab ini karena diminta oleh Abdur Rahman bin Mandi, seorang Imam ahli hadis yang terkemuka, agar menulis sebuah karangan kitab yang membahas "ushul fiqh". (Chalil, 2016, pp. 273-274)

2. Kitab al-Umm. Kitab inilah satu- satunya kitab besar yang disusun dan ditulis oleh Imam al-Syafi'i. Kitab ini menurut riwayat merupakan sebuah kitab figh yang besar yang tidak ada bandingnya pada masanya. Isi kitab ini menunjukkan kealiman dan kepandaian Imam al-Syafi"i dalam ilmu fiqh, karena susunan kalimatnya tinggi dan indah. Tepatlah kalau kitab ini dinamakan al-Umm, yang artinya yaitu " Ibu " bagi anakanak.

3. Kitab al-Musnad. Kitab ini adalah sebuah kitab yang istimewa karena berisi sandaran ( sanad) Imam al-
Syafi"i dalam meriwayatkan hadits-hadits Nabi Saw. Yang beliau himpun dalam kitab alUmm.

Metode istinbat Imam al-Syafi"i yaitu : Al-Qur"an, sunnah, ijma", qaul sahabat, qiyas dan istishab. Adapun penjelasannya sebagai berikut;

a. Al-Qur'an

Sebagaimana Imam-imam lainnya,Imam al-Syafi"i me nempatkan al-Qur'an pada urutan pertama, karena tidak ada sesuatu kekuatan apa pun yang dapat menolak keontetikan al-Qur"an. (alSyafi'i, th, pp. 21-23)

b. Sunnah

Menurut Imam al-Syafi"i

Sunnah merupakan sumber hukum yang kedua setelah alQur"an. Sunnah berfungsi sebagai pelengkap dalam menginterpretasikan al-Qur'an yang mujmal mutlaq,dan „amm. (al-Syafi'i, th, p. 190)

c. Ijma"

ljma" menurut Imam alSyafi"i ialah " tidak diketahui ada perselisihan pada hukum yang dimaksudkan". Beliau berpendapat, bahwa meyakini telah terjadi persesuaian paham semua ulama, yang dari jumlah banyak ulama tersebut tidak mungkin terjadi kekeliruan. (Ash-Shiddieqy, 1993, p. 91)

d. Qaul Sahabat

Imam al-Syafi'i menggunakan dan mengutamakan perkata an-perkataan sahabat atas kajian akal mujtahid, karena menurutnya pendapat mereka lebih baik dari mujtahid.

e. Qiyas

Muhammad Abu Zahrah me njelaskan bahwa ulama yang 
Rahmat Aripin : Kewenangan Wali Dalam Menentukan Pernikahan Janda Yang Belum Dewasa Menurut Imam Al - Syafi'l

DOI:10.24014/af.v18.i1.7062

pertama kali mengkaji Qiyas ( merumuskan kaidah-kaidah dan dasar-dasarnya ) adalah Imam al- Syafi"i. Imam al-Syafi"i menempatkan qiyas setelah alQur"an , hadits, ijma", dan fatwa sahabat. Beliau menggunakan qiyas dan menolak istihsan, karena menurutnya barang siapa menggunakan istihsan sama halnya dengan membuat syariat dengan hawa nafsu.

Syarat-syarat qiyas yang dapat diamalkan menurut Imam alSyafi"i adalah:

1. Orang yang mengambil qiyas harus mengetahui Bahasa Arab.

2. Mengetahui hukum alQur"an, Faraid, uslub, nasikh dan mansukh, „amm, khas dan petunjuk dilalah nash.

3. Mengetahui sunnah, qaul sahabat, ljma" dan ikhtilaf dikalangan ulama.

4. Mempunyai pikiran sehat dan prediksi bagus,sehing ga mampu membedakan masalah yang mirip hukumnya. (al-Syafi'i, th, pp. 510-511)

\section{Istishab}

Ditinjau dari segi bahasa istishab berarti persahabatan dan kelanggengan persaha-

batan.Imam al-Syaukani dalam kitabnya Irsyadal-Fuhul mengemukakan defenisi bahwa istishabadalah"dalilyang ndang tetapnya suatu perkara selama tidak ada sesuatu yang mengubahnya. (Zahrah, 2000, pp. 450-451)

Sementara itu Ibnu Qyyim memberikan defenisi bahwa istishab adalah melestarikan yang sudah positif dan menegaskan yang negative ( tidak berlaku ), yakni tetap tetap berlaku hukum asal, baik yang positif dan menegaskan yang negative ( tidak berlaku ), yakni tetap berlaku hukum asal, baik yang positif maupun negative sampai ada dalil yang mengubah statusnya. Menurut Imam al-Multaji, Imam alSyafi"i sering-sering menetapkan hukum dengan prinsip-prinsip Istishab. Yakni memberlakukan hukum asal sebelum ada hukum baru yang mengubahnya. Seperti setiap mukallaf pada dasarnya tidak punya beban apa-apa sebelum adanya ikatan yang dinyatakan dalam akad. (Bultaji, 1997, p. 38)

Kewenangan $\begin{gathered}\text { Wali } \\ \text { Menentukan }\end{gathered}$ Pernikahan
yang Banda
Imam al-Syafi'i
Imam al-Syafi"i hidup di Baghdad dan Mesir yang mana di kedua daerah tersebut, para wanita dinikahkan ketika menginjak baligh atau sudah mengalami menstruasi yaitu pada kisaran 10-16 tahun. (Rofiq, 1977, p. 61) Imam al- Syafi"i membahas lebih lanjut tentang masalah usia baligh dalam kitab al- Ummnya, sehingga seorang dipandang cakap hukum:

فلما كان من سنة رسول الله صلى الله

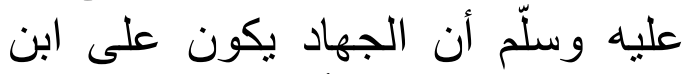

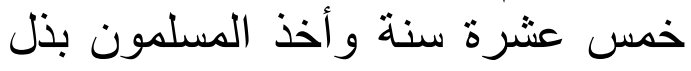
في الحدود وحكم الله بذللك في اليتامى النى الني فقال (حتى إذا بلغوا النكاح فإن آنستم

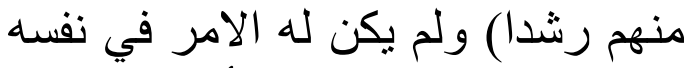

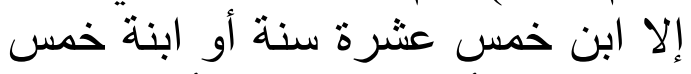

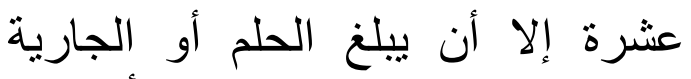
المحيض قبل ذللك فيكون لهما أمر في الأن أنفسهما.|(al-Syafi'i, th, pp. 21-23) 
Ketika ketentuan yang menyatakan bahwa kewajiban jihad dibebankan atas anak usia lima belas tahun itu menjadi sunnah Rasul dan hal ini diambil oleh kaum muslimin sebagai batas ketentuan serta Allah swt menetapkannya dalam hal anakanak yatim.: Allah swt berfirman:" sampai mereka cukup umur untuk kawin, kemudian jika menurutmu mereka telah cerdas ( pandai memelihara harta )" dan tidak ada baginya perintah yang berlaku untuk dirinya sendiri kecuali ia adalah anak laki- laki yang telah mencapai umur lima belas tahun, atau anak perempun yang berumur lima belas tahun; terkecuali bagi yang sudah bermimpi basah atau gadis yang haid sebelum usia lima belas tahun maka bagi keduanya berlaku perintah ( yang berlaku) untuk mereka berdua.

Tentu saja seorang gadis pada masa seperti itu belumlah bisa memutuskan sesuatu, terutama dalam masalah nikah oleh pikirannya sendiri. Bahkan di abad modern khususnya di Negara Indonesia, perempuan pada usia 1016 tahun masih dianggap anak-anak dan belum dewasa untuk menentukan pernikahannya sendiri. Maka dari itu Imam al-Syafi"i berpendapat bahwa nikah tanpa wali tidak sah. Menurut Imam alSyafi" $i$, kehadiran wali menjadi salah satu rukun nikah, yang berarti tanpa kehadiran wali ketika melakukan akad nikah perkawinan tidak sah. Menikah harus menghadirkan wali dalam prosesi akad nikah, baik wanita itu seorang gadis maupun janda. janda adalah wanita yang telah dicerai atau ditalak oleh suaminya baik cerai mati maupun cerai hidup, dan istilah janda belum berlaki yaitu janda yang dipermainkan oleh laki- laki lalu ditinggalkan. (Depdiknas, 2008, p. 617) Namun dalam Islam pengertian janda berbeda, yaitu; Perawan (Arab: al- bikr, al-bikarah; Inggris: virgin, virginity) dalam Islam adalah perempuan yang belum pernah melakukan hubungan intim (intercourse) dengan lelaki, baik dengan cara nikah atau zina. Dengan demikian, maka hilangnya selaput dara karena disebabkan oleh hal yang selain tersebut di atas seperti karena jatuh, kemasukan jari, atau haid itu tidak merubah status keperawanannya.

(alHusaini:, 2000, p. 47) Sebagaimana pendapat imam as-Syafi'i dalam kitab al-Umm; (al-Syafi'i, th, p. 76)

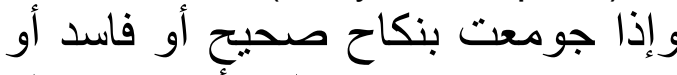
زنا صغيرة كانت بالغا أو غير أو فالغ كانت ثنيا.

Apabila seorang wanita dicampuri oleh seorang laki-laki dalam pernikahan yang syah maupun pernikahan yang tidak syah, atau dizinai, baik wanita itu telah baligh atau masih kecil, maka hukumnya sama seperti janda.

Imam al-Syafi"i menganggap batal suatu nikah yang lafadz ijabnya diucapkan seorang perempuan, baik gadis maupun janda, sekufu atau tidak, dengan izin wali ataupun tidak, secara langsung untuk dirinya ataupun sebagai wakil bagi orang lain. Menurut Imam al-Syafi'i, bapak lebih berhak menentukan perkawinan anak gadisnya. Hal ini didasarkan pada mafhum almukhalafah dari hadits yang menyatakan;

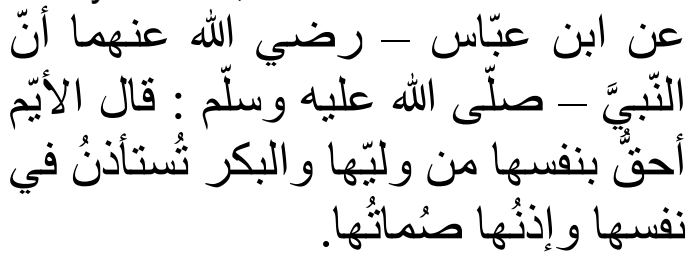


Rahmat Aripin : Kewenangan Wali Dalam Menentukan Pernikahan Janda Yang Belum Dewasa Menurut Imam Al - Syafi'l

DOI:10.24014/af.v18.i1.7062

Dari Ibnu Abbas, ia berkata," Rasulullah SAW bersabda, "Wanita janda lebih berhak terhadap dirinya daripada walinya, sedangkan gadis perawan dimintai izin persetujuannya mengenai dirinya, dan izinnya itu adalah diamnya," (HR.Jama"ah kecuali Al-Bukhari ). (Muslim, th, pp. 2545-2546)

Sehingga menurut Imam alSyafi"i izin gadis bukanlah satu keharusan tetapi hanya sekedar pilihan. Oleh sebab itu wanita yang masih kecil dan belum baligh, ayah atau kakeknya berhak untuk menikahkannya tanpa harus meminta izin kepadanya terlebih dahulu, karena ia belum banyak memahami berbagai hal tentang pernikahan. (al-Syafi'i, th, p. 69)

Adapun perkawinan seorang janda harus ada izin secara tegas dari yang bersangkutan, walaupun janda tersebut belum dewasa, menurut Imam al-Syafi"i wali nikah harus terlebih dahulu meminta izin kepadanya jika ingin menikahkan, wali nikah tidak boleh memaksa untuk menikahkannya dengan lakilaki yang tidak disukainya jika ia menolak untuk dinikahkan. Imam alSyafi"i berpendapat bahwa janda yang belum dewasa tidak boleh dipaksa nikah oleh ayahnya, hal ini sebagaimana ia jelaskan dalam kitab al-Umm:

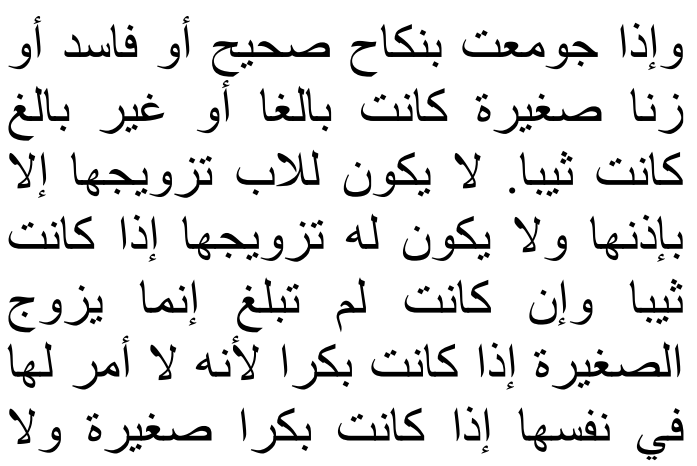

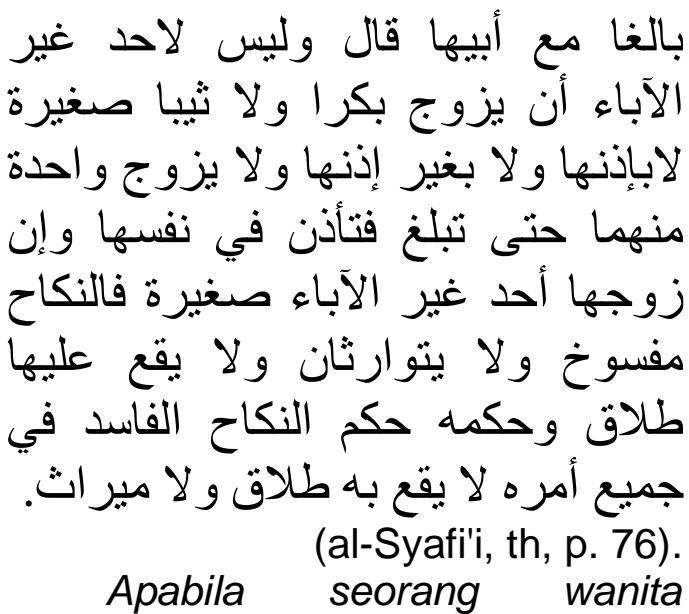

dicampuri oleh seorang laki-laki dalam pernikahan yang syah maupun pernikahan yang tidak syah, atau dizinai,baik wanita itu telah baligh atau masih kecil, maka hukumnya sama seperti janda, tidak boleh bagi bapak menikahkannya tanpa izin darinya. Imam Syafi"i berkata; Tidak ada hak bagi seorangpun selain bapak untuk menikahkan perawan atau janda yang masih kecil kecuali dengan restu darinya. Apabila seorang selain bapak menikahkan perempuan yang masih kecil, maka nikah itu dinyatakan batal. Pasangan suami isteri itu tidak saling mewarisi dan tidak berlaku padanya thalak ( cerai ), hukumnya sama seperti hukum nikah yang rusak semua sisinya, dimana pernikahan ini berkonsekuensi dengan adanya thalak maupun warisan.

Pernyataan Imam al-Syafi"i tentang kewenangan wali dalam menentukan pernikahkan janda yang belum dewasa tersebut adalah ayah tidak boleh menikahkan anak perempuannya yang sudah janda tetapi belum dewasa tanpa terlebih dahulu meminta izin kepadanya, alasan Imam al-Syafi"i yaitu karena beliau berpegang kepada kegadisan ( al-bikr ): maka beliau berpendapat bahwa gadis 
dewasa boleh dipaksa sedangkan janda belum dewasa tidak boleh dipaksa, karena janda yang belum dewasa atau dibawah umur walaupun ia belum dewasa tetapi dianggap sudah tidak gadis lagi. Imam al-Syafi"i berpegang kepada kejandaannya bukan belum dewasanya.

Adapun dasar hukum Imam al-Syafi"i tentang kewenangan wali dalam menentukan pernikahan janda yang belum dewasa adalah:

Sabda Rasulullah Saw:

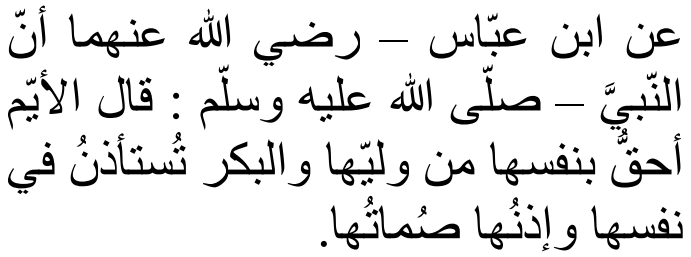

"Dari Ibnu Abbas, ia berkata," Rasulullah SAW bersabda, "Wanita janda lebih berhak terhadap dirinya daripada walinya, sedangkan gadis perawan dimintai izin persetujuannyamengenai dirinya, dan izinnya itu adalah diamnya," (HR.Jama"ah kecuali al-Bukhari ). (Muslim, th, pp. 2545-2546)

Imam al-Syafi"I berpendapat keumuman sabda Nabi SAW ini, mencakup janda dewasa dan yang belum dewasa. (Rusydi, 1989, p. 4) Imam al-Syafi"i juga berkata: Pada hadis ini terdapat petunjuk yang membedakan antara perawan dan janda mengenai dua hal: Pertama, mengenai izin keduanya, dimana izin perawan adalah sikap diamnya, Oleh karena itu, maka yang menyelisihinya adalah perkataan, sebab inilah yang merupakan lawan dari diam, dan ini (perkataan ) adalah izin perempuan janda. Kedua, kekuasaan keduanya terhadap diri masing-masing berbeda. Janda lebih berkuasa atas dirinya daripada wali, sedangkan yang lebih berkuasa atas perawan adalah walinya. Tapi perlu dicatat yang dimaksud dengan wali disini adalah ayahnya. (al-Syafi'i, th, p. 471) Karena janda yang belum dewasa ini juga mengetahui maksud pernikahan, maka dia tidak boleh dipaksa, berbeda dengan anak perawan. (az-Zuhaili, 2011, p. 182) Dia memberikan izin dengan lafal perwakilan boleh, karena makna dalam hadits ini adalah satu. Sesungguhnya perbedaan diantara anak perawan dan janda adalah pada hukum izin dan jenisnya. Anak perawan sunnah untuk diminta izinnya, dan pemberian izinnya cukup dengan diamnya. Sedangkan janda harus diminta izinnya dengan ungkapan pemberian izin yang jelas. (az-Zuhaili, 2011, p. 32)

\section{Kesimpulan}

Dari uraian diatas dapat diambil kesimpulan bahwa Imam al-Syafi"i berpendapat, seorang ayah dapat menikahkan anak perempuannya yang masih perawan tanpa izin dari anak tersebut baik anak tersebut masih kecil ataupun belum dewasa. Sedangkan janda yang belum dewasa seorang ayah tidak boleh memaksa untuk menikahkannya, ayah harus terlebih dahulu minta izin kepadanya. Jika ia menolak, maka ayah tidak boleh menikahkannya.

\section{Daftar Pustaka}

Abu Zahrah, Muhammad, Tarikh Madhahib al-Islamiyyah, Kairo: Dar Fikr al- Arabi, 2009

Al- Syafi,i ,Abi Abdullah Muhammad bin Idris, Al-Umm, Juz. 5, Beirut: Dar al- Kutub al-Ilmiah, th

Al- Syurbasyi, ahmad, Sejarah dan Biografi Empat Imam Mazhab, alih bahasa oleh Sabil Huda dan H.A. Ahmadi, Jakarta: AMZAH, 2008 
Rahmat Aripin : Kewenangan Wali Dalam Menentukan Pernikahan Janda Yang Belum Dewasa Menurut Imam Al - Syafi'l

DOI:10.24014/af.v18.i1.7062

Al-husaini, Taqiyuddin Abu Bakar bin Muhammad, Kifayatul Akhyar, alih bahasa oleh Syarifuddin Anwar, Mishbah Musthafa, Surabaya: Bina Iman,th

Al-Zuhaili, Wahbah, Figh Islam, alih bahasa Abdul Hayyie, dkk, (Jakarta:Gema Insani, 2011), jilid 9, hIm.Im.182.

Amin Suma ,Muhammad, Hukum Keluarga Islam di Dunia Islam,Jakarta: PT. Raja Grafindo Persada, 2004

AshShiddieqy, Teungku Muhamm ad Hasbi, Filsafah Hukum Islam, Jakarta: Bulan Bintang,1993, Cet.ke-5

Azmi, Ilmu Fiqh dan Hukum Keluarga Perpektif Ulama Tradisional dan Kontemporer, Pekanbaru:Fakultas dakwah dan komunikasi Uin Suska Riau, 201

Bultaji, Muhammad, Manhaj alTasyri" al-Islami fi al-Qarni alTsani al-Hijiri, Universitas Islam bin Sa"ud , 1997

Chalil, moenawar, Biografi empat serangkai Imam Madzhab, Jakarta: Gema Insani, 2016

Departemen Pendidikan Nasional, Tim Redaksi Kamus Bahasa Indonesia;Dendy Sugono, Sugiyono, Yeyen Maryani Kamus Besar Bahasa Indonesia,Jakarta : Balai Pustaka, 2008

Pamungkas,Imam dan Maman Surahman, Fiqh empat madzhab, Jakarta: AlMakmur, 2015

Rofiq,Ahmad, Hukum Perdata Islam di Indonesia, Jakarta: PT. Raja Grafindo Persada, 1977

Rusyd, Ibnu, Bidayat al-Mujtahid wa Nihayat al-Muqtasid, Beirut: dar al-Jiil, juz 2, 1409/1989

Sopyan,yayan

Tarikh

Tasyri",Jakarta: Gramata Publishing, th

Syarifuddin ,Amir, Garis-Garis besar Ushul Fiqh, Jakarta: Kencana Prenada Media Group, 2012, Cet.ke-1

Syaukani, Al-Imam, Ringkasan Nailul Authar, alih bahasa Amir Hamzah Fachruddin, Asep Saefullah, Jakarta: Pustaka Azzam,2006, Cet.ke-1 